before he receives a loan..$^{99}$ These plans specify what crops the borrower can grow and may, therefore, provide a system of crop regulation reminiscent of the recent AAA. ${ }^{100}$ Yet at best the regulation afforded by crop plans can provide only a partial solution to the problem presented by an unmanageable agricultural surplus.

\title{
TAXABILITY OF TRANSACTIONS BY A CORPORATION IN ITS OWN STOCK
}

THE power of a corporation to trade in its own stock is no longer contested in most jurisdictions. ${ }^{1}$ Although there was at one time some resistance to the concept of a corporation's holding an equity in itself, 2 the status of repurchased stock which is kept alive in the corporate treasury achieved early recognition. ${ }^{3}$ Corporations frequently acquire their own stock as satisfaction of a debt, as a donation, as consideration received in a sale of corporate property, or by way of a cash purchase. A wide variety of motives have impelled cash repurchases: elimination of dissident stockholders, reduction of invested capital in a period of business recession, or, less legitimately, reduction of opposition to the management. And, occasionally, a corporation trades in its own stock with a view to stabilizing the market price, widening the distribution of holdings or producing non-operating income. When treasury stock is resold at a figure in excess of the purchase price, this margin would seem to constitute an item of income which might be accorded tax recognition.

99. See Resettlenient AdMrinistration, op. cit. supra note 5, at 9.

100. United States v. Butler, 297 U. S. 1 (1936).

1. Scriggins v. Thomas Dalby Co., 290 Mass. 414, 195 N. E 749 (1935); Pabst v. Goodrich, 133 Wis. 43, 113 N. W. 398 (1907); Wormser, The Pouter of a Corfordtion to Acquire Its Oun Stock (1915) 24 Y ALE L. J. 177; Nussbaum, Acquisition by c Corporation of Its Own Stock (1935) 35 CoL. L. REv. 971; Comment (1932) 19 VA. L. REv. 85.

2. Trevor v. Whitworth, 12 A. C. 409 (1887); Currier v. Lebanon Slate Co., 56 N. H. 262 (1875); Peter v. Bruce, 157 Tenn. 131, 7 S. W. (2d) 43 (1923); see Companies Act, 1929, 19 \& 20 Geo. V, c. 23, \& 45; Levy, Purchase by an English Compary of Its Oun Shares (1930) 79 U. of PA. L. Rev. 45; Company Low and Proctice (1936) 80 Sor. J. 237.

3. Green v. Bissell, 79 Conn. 547 (1907); Leland v. Hayden, 102 Mass. 542 (1869); Knickerbocker Importation Company v. State Board of Assessors et al., $74 \mathrm{~N}$. J. Law 583, 65 Atl. 913 (1907). But see I. T. 2449, VIII-1 Cum. Bull. 101 (1929). For a listing of the motives underlying acquisition of treasury stock, consult MoNmGossens; Financial Handboox (2d ed. 1933) 528. 
The United States Board of Tax Appeals has recently handed down two rulings ${ }^{4}$ that a gain resulting from the purchase and resale of treasury stock falls within the definition of "gross income" provided by the Revenue Act" and must be included in the computation of net taxable income. The measure of the gain or loss was stated to be the difference, if any, between the purchase and resale prices. ${ }^{6}$ These decisions expressly overrule the Board's former position, grounded on an early precedent, ${ }^{7}$ which considered purchases and resales of treasury stock as non-taxable capital readjustments, affecting only the remaining stockholders and yielding no gain or loss to the corporation as an entity.

In one of these cases, ${ }^{8}$ a corporation made numerous purchases and resales of its stock over a period of years, allegedly for the purpose of preventing undue fluctuations in the market price of the shares and undue concentration of holdings. Without an exception, each of the years during the period involved yielded a net excess of resale over purchase prices. In line with the former position of the Board and in conformity with the Treasury Regulation then in force, ${ }^{9}$ the corporation consistently reported this excess as nontaxable income. The Board's decision disapproved of this practice on the ground that its early precedent and later decisions based upon it $^{\mathbf{1 0}}$ had been

4. R. J. Reynolds Tobacco Company, 35 B. T. A. 949 (1937); E. R. Squibb \& Sons, 36 B. T. A., June 30, 1937.

5. "Gross income' includes gains, profits, and income derived from . . . sales, or dealings in property, whether real or personal, growing out of the ownership or use of or interest in such property; . . . or the transaction of any business carried on for gain or profit, or gains or profits and income derived from any source whatever." $\$ 22$ (a) of Rev. Acts of 1936, 1934, 1932, 1928; 26 U. S. C. $\$ 22$ (a) (Supp. 1936).

6. R. J. Reynolds Tobacco Company, 35 B. T. A. 949, at 963 (1937); E. R. Squibb \& Sons, 36 B. T. A., June 30, 1937.

7. Simmons \& Hammond Manufacturing Co., 1 B. T. A. 803 (1925).

8. R. J. Reynolds Tobacco Company, 35 B. T. A. 949 (1937).

9. U. S. Treas. Reg. 74, Art. 66 (1928): "The proceeds from the original sale by a corporation of its shares of capital stock, whether such proceeds are in excess of or less than the par value of the stock issued, constitute the capital of the company. If the stock is sold at a premium, the premium is not income. Likewise, if the stock is sold at a discount, the amount of the discount is not a loss deductible from gross income. If for the purpose of enabling a corporation to secure working capital or for any other purpose, the shareholders donate or return to the corporation to be resold by it certain shares of stock of the company previously issued to them, or if the corporation purchases any of its stock and holds it as treasury stock, the sale of such stock will be considered a capital transaction and the proceeds of such sale will be treated as capital and will not constitute income of the corporation. A corporation realizes no gain or loss from the purchase or sale of its own stock." Identical provisions appear in U. S. Treas. Reg. 77, Art. 66 (1932) ; U. S. Treas. Reg. 69, 65, 62, Art. 543 (1926, 1924, 1922) ; U. S. Treas. Reg. 45, Art. 542 (1918).

10. Simmons \& Hammond Manufacturing Co., 1 B. T. A. 803 (1925); Cooperative Furniture Co., 2 B. T. A. 165 (1925) ; Hutchins Lumber \& Storage Co., 4 B. T. A. 705 (1926) ; Houston Brothers Co., 21 B. T. A. 804 (1930); cf. J. H. Johnson, 19 B. T. A. 840 (1930), aff'd, Johnson v. Comm'r of Int. Rev., 56 F. (2d) 58 (C. C. A. 5th, 1932). 
at least implicitly overruled both by various court reviews of its holdings in analogous cases $^{11}$ and by a revision of the Treasury Regulation pertaining to dealings in treasury stock. ${ }^{12}$ Taxability was reaffirmed shortly thereafter in a case ${ }^{13}$ where a corporation purchased shares of its own stock and resold them at a price stipulated in an agreement with another corporation organized primarily to acquire stock for distributors of the company's products. Having on hand no shares with which to carry out its agreement, the corporation purchased a sufficient number on the open market at a total price less than the proceeds on resale. The amount of this excess was held by the Board to be a taxable profit.

At the outset, it is essential for purposes of clarity to isolate the issue of taxability of a corporation's transactions in its own stock from other taxable phases of the same transactions. The Board's failure to make this distinction has led to confusion in the historical development of the problem. Thus, shortly after the Board had held a cash purchase and resale by a corporation of its own stock to be non-taxable, ${ }^{14}$ a situation arose where the corporation received its own stock as part of the consideration tendered by a purchaser of certain corporate assets. ${ }^{15}$ Such exchanges in kind, aside from the presence of the stock in the consideration, would normally be handled in accord-

11. Walville Lumber Co. v. Comm'r of Int. Rev., 35 F. (2d) 445 (C. C. A. 9th, 1929), rev'g, 12 B. T. A. 152 (1928) ; Comm'r of Int. Rev. v. S. A. Woods Mrach. Co., 57 F. (2d) 635 (C. C. A. 1st, 1932), cert. denicd, 287 U. S. 613 (1932), rev'g, S. A. Woods Machine Co., 21 B. T. A. 818 (1930), (1933) 27 InL L. REy. 566; Comm'r of Int. Rev. v. Boca Ceiga Development Co., 66 F. (2d) 1004 (C. C. A. 3d, 1933), reig, Boca Ceiga Development Company, 25 B. T. A. 941 (1932); Dorsey Co. v. $>$ Comm'r of Int. Rev., 76 F. (2d) 339 (C. C. A. 5th, 1935), cert. denied, 296 U. S. 589 (1935), rev'g, Dorsey Co., 30 B. T. A. 1463 (1935); Allyne-Zerk Co. v. Comm'r of Int. Rev., 83 F. (2d) 525 (C. C. A. 6th, 1936), aff'g, Allyne-Zerk Company, 29 B.T.A. 1194 (1934). But $c f$. Johnson v. Comm'r of Int. Rev., 56 F. (2d) 58 (C. C. A. 5th, 1932), cert. denicd, J. H. Johnson v. Burnet, 286 U. S. 551 (1932), aff'g, J. H. Johnson, 19 B. T. A. 840 (1930).

12. "Whether the acquisition or disposition by a corporation of shares of its own capital stock gives rise to taxable gain or deductible loss depends upon the real nature of the transaction, which is to be ascertained from all its facts or circumstances. . . . if a corporation deals in its own shares as it might in the shares of another corporation, the resulting gain or loss is to be computed in the same manner as though the corporation were dealing in the shares of another. So also if the corporation receives its own stock as consideration upon the sale of property by it, or in the satisfaction of indebtedness to it, the gain or loss resulting is to be computed in the same manner as though the payment had been made in any other property. Any gain derived from such transactions is subject to tax, and any loss sustained is allowable as a deduction where permitted by the provisions of the Act." U. S. Treas. Reg. 94, Art. 22 (a)-16 (1936) ; U. S. Treas. Reg. 77, Art. 66 (1932) as amended by Treas. Dec. 4430 (May 2, 1934); see note 9, supra.

13. E. R. Squibb \& Sons, 36 B. T. A., June 30, 1937.

14. Simmons \& Hammond Manufacturing Co., 1 B. T. A. 803 (1925).

15. Behlow Estate Co., 12 B. T. A. 1365 (1928); New Jersey Porcelain Co., 15 B. T. A. 1059 (1929). 
ance with the provisions of the Revenue Act ${ }^{16}$ which establish the fair market value of all property other than cash received in a disposition of assets as a basis for determining whether a taxable gain or deductible loss was realized in relation to the original cost of those assets to the corporation. A wide area for tax evasion would be opened if all such exchanges in kind were exempted from taxation merely because the corporation's stock entered into the consideration tendered for the assets. The Board therefore approved taxation of the capital gain on the corporate assets sold. This desirable result was clouded, however, by failure to separate the transaction into its two component parts, namely, the sale of the corporate assets and the repurchase of the stock. For every deal by a corporation in its own stock may be reduced to the equivalent of a cash transaction. Thus, when a corporation tenders property other than cash for its stock, the transaction may be viewed as a sale of the property for cash with a simultaneous use of the proceeds as payment for the stock. The Board's failure to apply this analysis became apparent in a subsequent decision ${ }^{17}$ reaching an opposite result on a similar fact situation. The reversal was apparently motivated by a groundless desire to achieve consistency with its position regarding cash repurchases and resales.

Another confusing element arose in a case where a corporation acquired its stock as the realization of corporate income. ${ }^{18}$ The corporation had received its own stock in settlement of a judgment recovered against a stockholder for patent infringement. The fair market value of that stock was held to constitute taxable income. In reaching this conclusion, the court set up as a general criterion for determining when a transaction by a corporation in its own stock constituted a "bona fide capital, readjustment" or a taxable income-producing deal, an examination into "the real nature of the transaction involved." 18 But this standard has implications broader than the precise application necessary for the decision in that case. Recognition of the dual nature of the transaction as composed both of a realization of prior accrued income and an acquisition of stock was itself sufficient to distinguish

16. $\S 111$ (b) of Rev. Acts. of 1936, 1934, 1932, $\S 111$ (c) of Rev. Act. of 1928, $\S 202$ (c) of Rev. Acts. of 1926, 1924, 26 U. S. C. 111 (Supp. 1936). See U. S. Treas. Reg. 77, 74, Art. 69 (1932), (1928); U. S. Treas. Reg. 69, Art. 546 (1926); U. S. Treas. Reg. 62, Arts. 546, 563 (1922), as amended by Treas. Dec. 3206.

17. Houston Brothers Co., 21 B. T. A. 804 (1930).

18. S. A. Woods Machine Co., 21 B. T. A. 818 (1930), rev'd, Comm's of Int. Rev. v. Woods Mach. Co., 57 F. (2d) 635 (C. C. A. 1st, 1932), (1933) 27 ILL. L. REv. 566.

19. These two phrases have led to later confusion, since they implied that the intent on receipt by a corporation of its stock should determine whether it should be taxed. Actually, the court was applying taxation to the prior accrued income from the patent infringement judgment as measured by the fair market value of the stock. In a similar situation where a corporation received its own stock in satisfaction of a debt, previously allowed as a deductible loss, the stipulated value of those shares was held income. Houghton and Dutton Company, 26 B. T. A. 52 (1932). In both situations, the transaction should be viewed as if cash were received and reinvested by the corporation in its stock. 
the fact situation from the more common cash repurchase..$^{20}$ It seems unfortunate, therefore, that the recital of this vague criterion was repeated by the Board in a subsequent line of decisions, ${ }^{21}$ involving independent sources of gain, so as to confuse later treatment of cash transactions by a corporation in its own stock.

Similarly, when a corporation purchased its own shares for a subsequent resale to its employees at a substantially lower figure, the difference between the purchase and resale prices was held to be a deductible expense. 2 Here, again, taxable recognition is based on an independent factor, since resale under similar circumstances to parties other than employees would constitute a cash transaction of the type principally in issue, which at that time was not treated as resulting in a deductible loss. ${ }^{23}$ The deductible expense was allowed only because the margin represented a bonus equally deductible if the corporation had merely paid out cash to the employees to the extent of the difference between the purchase and resale prices.

Preliminary to any attempt to determine whether a corporation can realize an independent gain or loss upon transactions in its own stock, an inquiry must be made into what is meant when it is said that a corporation gains or loses. In a sense, the corporate entity can never gain or lose. From the standpoint of the accounting balance, every change in net assets, whether in the nature of income or capital, is necessarily accompanied by a corresponding change in the proprietorship accounts. But this theory is inconsistent with the

20. The court comes closer to a recognition that in this situation an independent factor is operating by stating that the receipt of stock here vas equivalent to the payment of the judgment in cash and the investment of such proceeds by the company in its own stock. But even here it is difficult to determine whether the court realized it was taxing the phase analogous to a receipt of cash while exempling, by not considering the taxable incidence of, the analogous reinvestment by the company in its own stod: The distinction was recognized and followed in a later case where corporate assets were sold to a stockholder for cash and certain shares of the stock of the corporation. Dorsey Co. v. Comm'r of Int. Rev., 76 F. (2d) 339, at 340 (C. C. A. 5th, 1935), cert. denied, 296 U.S. 589 (1935). The "receipt of cash" thus may be taxable for a reason apart from the principal issue as to whether tax recognition should be accorded a cash repurchase by a corporation of its own stock. Sec PAUL \& Menters, LAy of Federal Income Taxation (1934) \$26.99.

21. Houghton and Dutton Company, 26 B.T.A. 52 (1932); Boca Ceiga Development Company, 25 B. T. A. 941, rev'd, Comm'r of Int. Rev. v. Boca Ceiga Development Co., 66 F. (2d) 1004 (C.C.A. 3d, 1933) ; Niagara Share Corporation of Delaware, 30 B.T.A. 668 (1934); Peerless Investment Company, 30 B. T.A. 491, 496 (1934), aff'd, Peerless Investment Company v. Comm'r of Int. Rev., 80 F. (2d) 427, (C. C. A. 9th, 1935) ; Allyne-Zerk Company, 29 B.T. A. 1194 (1934); aff'd, Allyne-Zerk Co. v. Comm'r of Int. Rev., 83 F. (2d) 525 (C. C. A. 6th, 1936) ; cf. Spear \& Co. v. Heiner, Collector of Int Rev., 54 F. (2d) 134 (W. D. Pa. 1931).

22. Haskell \& Barker Car Co., 9 B.T. A. 1087 (1928) ; cf. E. R. Squibb \& Sons, 36 B. T. A., June 30, 1937.

23. See note 10 , supra. 
existing system of double taxation, ${ }^{24}$ for it permits taxation only at the point of receipt of dividends by stockholders. Under the present order, the taxing authorities do not await distribution of increments to the corporate fund but seize upon the corporate entity as a convenient unit against which to assess the levy upon the additions to the corporate fund. But as evidenced by the exemption from taxation of the proceeds from flotation of additional unissued stock, ${ }^{25}$ not every increase in the net assets of the corporation has taxable incidents. Therefore, it is always essential to look behind the corporate entity to the proprietorship interests. Taxes have been assessed only against those changes in the corporate fund of net assets which have not been accompanied by increases or decreases in the number of proprietorship claims against that fund. ${ }^{26}$ An exception is made only in the case of cash dividends, since allowance of a deductible loss to the corporation for dividend payments would be inconsistent with the present scheme of double taxation. ${ }^{27}$

The Board's early holding ${ }^{28}$ that a corporation's deals in its own stock were non-taxable, avoided the real issue by stating that the corporate entity neither gained nor lost by transactions in its own stock ${ }^{20}$ for as has been shown above, a corporate entity never profits or loses. The real question was whether or not there had been any fluctuations in the corporate fund unaccompanied by a change in the number of proprietorship claims. In that case the corporation had purchased the entire holdings of two of its stockholders for cash at a premium over the proceeds on original issue, and later in the same year resold these shares to two other stockholders for less than the purchase price but more than the proceeds on original issue. The company claimed the difference between the purchase and resale prices as a deductible loss. The Board, in denying this claim, stated that it regarded the transactions entirely

24. There is general agreement on the principle that some compromise between the theory of corporate entity and complete identification of corporation and stockholders must be made for purposes of double taxation. Eisner v. Macomber 252 U.S. 189 (1919); Merchants Loan \& Trust Company v. Smietanka, 255 U.S. 509 (1921). See Finkelstein, The Corporate Entity and the Income Tax (1935) 44 Y YLE L. J. 436; Ballantine, Corporate Personality in Income Taxation (1921) 34 HARv. L. Rev. 573.

25. See note 9, supra.

26. Changes in the corporate fund which will subject a corporation to taxation do not, of course, include mere fluctuations in the market value of assets. An appreciation in the value of property, unrealized by conversion, is not income even if recognized by a book revaluation. Sprunt \& Sons, Inc, 24 B. T. A. 599, 621 (1931).

27. The exact converse of a cash dividend, but occurring less frequently, is pro rata contributions by stockholders without the issue of additional stock, which likewise is not given tax recognition. U. S. Treas. Reg. 45, Art. 543 (1918); U. S. Treas. Reg. 62, 65, 69; Art. 544 (1922), (1924), (1926) ; U. S. Treas. Reg. 74, Art. 67 (1928) ; U. S. Treas. Reg. 77, Art. 67 (1932).

The Treasury Regulations describe these payments as in the nature of voluntary assessments representing an additional price paid for the shares of stock held by the individual shareholders.

28. Simmons \& Hammond Manufacturing Co., 1 B. T. A. 803 (1925).

29. Id. at 808 . 
as capital readjustments, essentially a matter between the corporation and its stockholders as separate entities, and from which the corporation itself incurred no gain or loss, despite the apparent status of treasury stock as an independent asset in some instances and despite the benefit or detriment to the remaining stockholders in the measure that the purchase and resale prices fell short of or exceeded the per share book values before and after the acquisition and resale.

Thus the corporation's purchase of its own stock was visualized as the repayment of a proportionate share of the invested capital and accumulated earnings to the retiring stockholder, and the resale of that stock as a new contribution of capital by the incoming stockholder. This conception of the transaction implied a cancellation and retirement between the points of purchase and resale that did not in fact occur. If there had been a retirement, however, the assignment of non-taxable status to the transaction would have then been proper since the decrease in the corporate fund at the time of repurchase would have been accompanied by a reduction in the number of proprietorship claims against it, and the increase at sale of new stock, by a rise in the proprietorship claims. But this implication contrary to fact overlooked the distinction between treasury and unissued stock. This attitude may, perhaps, be identified with the reluctance of courts to recognize the anomaly" of a corporation owning an equity in itself, ${ }^{30}$ the term "capital readjustment" obviating the necessity of facing the fact that treasury stock is kept alive between purchase and resale.

The recent rulings of the Board ${ }^{31}$ reversing its earlier position recognized the ready marketability and other potentialities of treasury stock when cancellation and retirement do not intervene between its acquisition and resale. The Board endowed treasury stock with the status of an asset for tax purposes by regarding the acquisition not as a redistribution of proportionate ownership but the receipt of "property" having a substantial resale value. While accounting authorities have been in substantial accord that it is incorrect to term treasury stock an asset, ${ }^{32}$ corporate balance sheets have frequently shown it as an asset if there is an intent to resell. ${ }^{33}$ This motive is sometimes presumed from the retention of reacquired stock in the cor-

30. See note 2, sipra.

31. R. J. Reynolds Tobacco Company; E. R. Squibb \& Sons, both sipra note 4.

32. Hatfield, Accounting (1928) 181-183; 1 Kester, Accountimg, Theom and Practice (3d ed. 1933) 370; Mlontgoarery, Audrtitic, Treory and Practice (5th ed. 1934) 244-246; Montgoarery, Federal TAx Handeoor (1932) 109; Pato:;, Accountants' Handbook (2d ed. 1936) 934; Peloubet, Audit Wonkizg Papens (1937) 113, 143; Securities and Exchange Cossrission, Instruction: Book For Forar 10K.

33. See Hatfield, op. cit. supra note 32, at 182; Gramass asid Katz, Accousitio in Law Practice (1932) 155; Paton, op. cit. supra note 32, at 934; Peloudet, op. cir. supra note 32 , at 113,114 . This practice has received specific support from Mifo:tgomery, Auditing, Theory and Practice (5th ed. 1934) 246, 402. 
porate treasury without cancellation and retirement. ${ }^{34}$ Under these circumstances, the purchase and resale approximate a transaction in the stock of another corporation. Accountants still prefer, however, to treat the repurchase of stock as a readjustment of the proprietorship account, ${ }^{35}$ the book entry conforming to that used in the reduction of liabilities to third parties, i.e., an offset to the capital stock account with adjustment for any discount or premium in terms of stated value being referred to a segregated surplus account. ${ }^{36}$ Only when there is intent to resell in the immediate future is sanction lent to the designation of treasury stock as an asset valued at cost, 37 provided it is not listed among current assets. ${ }^{38}$ Realistically, stock of this type appears to have many advantages over unissued stock, especially when an open market is maintained in the securities of the particular company involved. Such a market offers a ready opportunity for a relatively immediate turnover, since little consideration need be given to pre-emptive rights, ${ }^{30}$ or to the requirements of the Securities Act of $1933,{ }^{40}$ or to the legality of the resale price. ${ }^{41}$ It is apparent, however, that consideration of treasury stock as an asset depends upon subsequent resale and, therefore, its asset quality

34. See note 33, stipra.

35. See note 32 , supra.

36. Committee on Statistical Reporting and Uniform Accounting for Industry, Report to the Business Advisory and Planning Council for the Department of Commerce, Reports to Stockholders (1934) 19; PAToN, op. cit. supra note 32, at 935, KESTER, op. cit. supra note. 32, at 369; GrABAM AND KATZ, op. cit. supra note 33, at 157; HATFIELD, op. cit. supra note 32, at 183. Donations of treasury stock for resale often occur because a substantial portion of the original issue was transferred to corporate promoters in consideration for property and because resale is necessary to provide working capital for the operations of the corporation. If this property was overvalued at the time of original issue, the accounting record of the donation should be a credit to the property and a debit to capital stock accounts, rather than a listing of treasury stock as an asset with a corresponding credit to surplus.

37. See note 32, supra.

38. Letter from the Committee on Stock List of the New York Stock Exchange to the Governing Committee of the Exchange (December 18, 1933); Committee on Statistical Reporting and Uniform Accounting for Industry, Report to the Business Advisory and Planning Council for the Department of Commerce, Reports to Stockholders (1934); Peloubet, op. cit. supra note 32, at 113. As in almost all these suggestions and regulations concerning corporate accounting, the Securities and Exchange Commission and the Committee on Stock List of the New York Stock Exchange are primarily interested in full disclosure to stockholders.

39. Borg v. International Silver Co., 11 F. (2d) 143 (S. D. N.Y. 1926); aff'd, 11 F. (2d) 147 (C.C. A. 2d, 1926) ; Dunn v. Acme Auto and Garage Co., 168 Wis. 128, 169 N. W. 297 (1918); see Fletcher, CoRporations (perm. ed. 1931) $\$ \$ 2859,2860$.

40. 48 Stat. 74-88 (1933), as amended by 48 Stat. 905-909 (1934), 15 U.S.C. § 77a-z (Supp. 1936), 133 C. C. H. 1936 Stock \& Bond Law Serv., §§ 101-238.

41. Furlong v. Johnston, 204 N. Y. Supp. 710, 209 App. Div. 198 (1924), aff'd, 239 N.Y. 141, 145 N.E. 910 (1924) ; see Enright v. Heckscher, 240 Fed. 863, 874 (C. C. A. 2d, 1917); Borg v. International Silver Co., 11 F. (2d) 143, 146 (S. D. N. Y. 1926); aff'd, 11 F. (2d) 147, 149 (C. C. A. 2d, 1926). 
is of a potential nature. ${ }^{12}$ But the prevalence of purchases with intent to resell and actual resale has lent support to this suggested method of treatment, for the treasury stock in these circumstances assumes only a transient position on the corporate books. ${ }^{13}$ Since the validity of this method depends on the fact of a subsequent resale, no tax would seem to result where the stock is actually retired.44

In contrast with the earlier approach, which regarded the purchase and resale as unrelated transactions, the recent holdings ${ }^{15}$ of the Board realistically view the transactions as a unit. By so doing, they recognize that there has been a net change in the corporate fund, measured by the difference between the purchase and resale prices, but without any ultimate variation in the number of proprietorship claims. ${ }^{16}$ This is true in spite of the apparent reduction in the number of proprietorship claims at the point of purchase and a seeming expansion of these at the point of resale. Actually, these transactions are rendered one by the fulfillment of the potentialities of treasury stock as a means of replenishing the proprietorship fund. Thus, it is unnecessary to regard the expenditure on repurchase as a decrease in the corporate fund since this potentiality justifies replacement of the cash expended by valuntion of treasury stock at cost. ${ }^{47}$

Due to the development of hybrid securities which tend to obliterate the distinction between stocks and bonds, there is some question as to whether the same tax treatment should be accorded a repurchase of stock as is now applied to the repurchase of bonds. ${ }^{48}$ Where there is an actual cancellation

42. Note language of Hand, C. J., in Borg v. International Silver Co., 11 F. (2d) 147,150 (C. C. A. 2d, 1926).

43. See note 32, supra.

44. J. H. Johnson, 19 B. T. A. 840 (1930), aff'd, Johnson at al r. Comm'r of Int. Rev., 56 F. (2d) 58 (C.C.A. 5th, 1932). See Paul \& Merteis, Law of Feneral Income Taxation \$6.40; cf. Allyne-Zerk Company, 29 B.T.A. 1194 (1934), off'd, Allyne-Zerk Co. v. Comm'r of Int. Rev., 83 F. (2d).525 (C. C. A. 6th, 1936).

45. R. J. Reynolds Tobacco Company, E. R. Squibb \& Sons, both sipra note 4.

46. The same criterion is applicable to transactions by one member of a legally affiliated group in the stock of another. Shortly after the Board's decision in Simmons \& Hammond Manufacturing Co., 1 B. T. A. 803 (1925), that transactions by a corporation in its own stock were non-taxable, this rule was extended to these transactions within a legally affiliated group. Farmers Deposit National Bank and Affiliated Banks, 5 B. T. A. 520 (1926); Interurban Construction Co., 5 B. T. A. 529 (1926); H. S. Crocker Co., 5 B. T. A. 537 (1926); United Drug Co. v. Nichols, 21 F. (2d) 160 (D. Mass. 1927); Union Trust Co. of New Jersey, 12 B. T. A. 688 (1928). The tendency appears now to be to regard affiliation wholly immaterial in considering the question of taxability. Consolidated Utilities Co. v. Comm'r of Int. Rev., 84 F. (2d) 548 (C. C. A. 5th, 1936); (1936) 14 TAX MAG. 501. In regard to what constitutes legal affiliation, see 49 Stat. 1698 (1936); $\S 141$ (d) of Rev. Acts of 1936, 1934, 1932, 26 U. S. C. \$141 (d) (Supp. 1936).

47. Montgoniery, Auditing, Theory and Practice (5th ed. 1934) 246.

48. Premium or discount incident to the retirement of bonds is at present accorded tax recognition. United States v. Kirby Lumber Co., 284 U. S. 1 (1931), (1932) 
and retirement of.stock at the time of purchase, the difference between the retirement figure and the proceeds on original issue would be taxable on this analogy. But when common stock is involved there is no basis for taxing the corporation since this difference results not only in a change in the corporate fund but also in the number of ownership claims. The distinction lies in the fact that discount or premium incident to retirement of bonds represents a net change in the common stock equity, whereas a difference between the repurchase price and the proceeds on original issue of common stock does not necessarily represent a fluctuation in the equity. This follows from the fact that the common stock equity at the time of retirement of some of the shares may be in excess of the original invested capital due to an accumulation of undistributed earnings or an increment in the market value of certain assets.

Thus, it is only in the field of hybrid securities that the bond analogy is relevant. The factor determining whether a security falls within the category of a bond for this purpose would appear to be the attribute of a fixed liquidation amount. The purchase and retirement of preferred stock might accordingly be subjected to the same tax treatment as the repurchase of bonds. However, the tax administration and the courts have indicated a settled policy in favor of classifying preferred with common stock for purposes of refusing to recognize taxable status of repurchases. ${ }^{40}$ Hence, although a corporation purchased its preferred stock to fulfill a sinking fund provision at a premium over the proceeds on original issue, the court held that the presence of the sinking fund provision was not sufficient to create a creditordebtor relation which would bring the purchase within the rule applied to bonds and, therefore, that no loss was properly deductible. ${ }^{50}$

If tax recognition were given to the repurchase of hybrid securities, the absence of immediate retirement would raise the same question of the materiality of intent as in the case of bonds. For, as to bonds, taxable incidence arises only when the repurchase is accompanied by actual retirement or where

32 Col. L. Rev. 137, (1932) 45 HARv. L. Rev. 744, rev'g, 44 F. (2d) 885 (Ct. Cl. 1930), aff'g, 19 B. T. A. 1046 (1930); Garland Coal \& Mining Co. v. Helvering, 75 F. (2d) 663 (App. D. C. 1935), aff'g, 28 B. T. A. 348 (1933). For general discussion of this field, see Comment (1931) 40 Yale L. J. 960; (1933) 11 N. Y. U. L. Q. Rev. 269. For more specific analysis of particular phases, see Wakefield, Gain on Retirement of Bonds Issued for Property (1933) 11 TAX MAG. 249; (1936) 46 YALE L. J. 314 (tax incidents on retirement of assumed bonds).

49. Atlantic Carton Corporation, 2 B. T. A. 380 (1925) ; Liberty Agency Co., 5 B. T. A. 778 (1926) ; Simmons Company, 8 B. T. A. 631 (1927). But cf. Ohio Central Telephone Company, 28 B. T. A. 96 (1933). The Board has in the past in related questions looked more to the form of the security issue than to its substance. That this reliance on terminology provides an inadequate basis for a distinction between interest and dividends in considering the allowance of deductions therefor, see Comment (1930) 39 Yale L. J. 1025.

50. Jewel Tea Co., Inc. v. United States, 15 Fed. Supp. 56 (S. D. N. Y. 1936). 
at that time there is no contemplation of future resale.51 Because inquiry into intent complicates tax administration, it might be well discarded in favor of a more arbitrary system of uniform tax recognition of the repurchase transaction. By this revision all purchases of securities possessing a fixed liquidation figure would be taxed and the resale transaction considered as a new flotation of a fixed liability. But it is extremely unlikely that the tax authorities and the courts will depart from their present policy of denying taxability to repurchase of any security other than a bond or note.

Whatever disposition is made of the problems relating to hybrid securities, it would seem that where common stock is involved the theory now adopted by the Board is to be preferred. It accords with the realities of the situation by considering treasury stock, in effect, an asset when resale ensues, with the resulting gain or loss taxable or deductible. Moreover, the new rulings are consistent with the desirable practice of exempting purchases from tavation without the necessity of inquiry into intent where cancellation and retirement do not immediately ensue. Unfortunately, language is used which renders uncertain the materiality of the motive behind a particular transaction as an element in determining its taxable status. 52 Complete departure from questions of intent should characterize treatment of these transactions in the future. To the extent that the exemption of "bona fide capital readjustments" implies materiality of intent to retire the stock after repurchase, this consideration is eliminated by taxation only at the point of resale. To the extent that this exemption is inserted to provide for situations in which independent sources of gain are present, these situations are better handled in their separate elements, and the acquisition and sale of stock subjected to consistent tax treatment regardless of whether cash or property is paid out or received in the deal. ${ }^{53}$

51. Intent to retain bonds for resale seems to exempt the repurchase from taxation. Treatment of repurchased bonds as a deduction from liabilities on the corporate balance sheet has been held decisive of an intent to retire Garland Coal \& Mining Co. v. Helvering, 75 F. (2d) 663 (App. D. C. 1935), aff'g, 28 B. T. A. 348 (1933). But see Transylvania Railroad Company, 36 B. T. A., July 16, 1937.

52. See note 6 , supra.

53. Once tax recognition is extended to these cash purchases and resales, the further question arises as to whether the gain (or loss) is ordinary income or capital gain. The choice is important both because different rates [Compare 49 Stat. 1655, (1936), 26 U. S. C. $\$ 13$ (b) (Supp. 1936) (income tax) with 49 STst. 1691 (1936), 26 U. S. C. $\$ 101$ (a) (Supp. 1936) (capital gains)] apply and because capital losses are not fully deductible. 49 Stat. 1692, 26 U. S. C. 101(d) (Supp. 1936); 372 C. C. H. 1937 Fed. Tax Serv. $\$ 862,867$. The definition of a capital asset in 49 SrAт. 1691, 26 U. S. C 1016 (1934) seems broad enough to include treasury stock See Ignaz Schwinn, 9 B. T. A. 1304, 1307 (1928) and cases cited therein. Apparently the Board and courts have not yet turned their attention to this problem because of the recency of extension of tax recognition to transactions by corporations in their own stock. 